\title{
Reflections of globalization and health informatics on medical ethics
}

\author{
Gül Sultan Özeren*, Huriye Demet Cabar
}

School of Health, Sinop University, Sinop, Turkey

\begin{tabular}{|c|c|}
\hline ARTICLE INFO & ABSTRACT \\
\hline $\begin{array}{ll}\text { Article History } & \\
\text { Received } & 25 / 02 / 2013 \\
\text { Accepted } & 09 / 04 / 2013\end{array}$ & $\begin{array}{l}\text { Today, all humanity is moving with increasing speed towards being a global information } \\
\text { society by following and experiencing social, cultural, economical, scientific and } \\
\text { technological advancements. Implementation of health informatics provides disposal of } \\
\text { manpower, short hospitalization durations, time saving by its effect on work process, }\end{array}$ \\
\hline $\begin{array}{l}\text { * Correspondence to: } \\
\text { Gül Sultan Özeren } \\
\text { School of Health, Sinop University, } \\
\text { Sinop, Turkey } \\
\text { e-mail: qulsultan@gmail.com }\end{array}$ & $\begin{array}{l}\text { health is a fundamental human right and humans possess equal rights to receive equal, } \\
\text { attainable, cost-free and qualified health care to remain healthy, to improve their health, } \\
\text { and to regain health when they fall ill. Today, common standards are required providing } \\
\text { the opportunity to share health information in case of necessity, as well as audit and } \\
\text { inspection systems to maintain information secrecy. It is compulsory for nurses who } \\
\text { constitute a major group among health care providing groups to improve their global }\end{array}$ \\
\hline $\begin{array}{l}\text { Keywords: } \\
\text { Ethic } \\
\text { Globalization } \\
\text { Health Information }\end{array}$ & $\begin{array}{l}\text { brought about by globalization. Education looms large to act an important role in the } \\
\text { struggle for ethics, one of the essential components of global health issue and to achieve } \\
\text { all these qualities. Thence, this article aims to enlighten the reflections of globalization } \\
\text { and health informatics on health care ethics. }\end{array}$ \\
\hline
\end{tabular}

Healthcare

Nursing information

\section{Introduction}

Knowledge and sharing of information, along with technological advancements of today's society is one of the most essential elements of globalization (Dilmen, 2007). In our country, security concerns and the access charges are the largest obstacles against the technological development and the adaptation to the information and communication technologies (Çukurçayır and Çelebi, 2009).

Global health has been defined as a broad concept comprising world-wide health and social, economical, political, technological, environmental and cultural issues that affect health care. Like in all disciplines, global health is accepted as application and resarch area by nursery, too (Kaya, 2010). This article aims to enlighten the reflections of globalization and health informatics on health care ethics.

\section{Informatics, health informatics and nursery informatics systems}

Informatics system can be characterized as a computer system which uses data-based administration system to save and access data. "Health Informatics Systems" is the overall name given to establishment, shaping and sharing of information and data constituted by medical improvements and consequently determination of patients' care and treatments (Ömürbek and Altın, 2009). The nursing informatics is defined as the collective uses of the computer science, information science and nursing science in the all fields of the nursing care, from planning to evaluation. The development of informatics in the field of nursing has gained momentum with the adoption of nursing informatics as a specialty by the American Nurses Association in the year 1992 (Seçginli and Erdoğan, 2012). The use of information technologies as an alternative to the various cost-cutting strategies in the health care facilities, is increasing in the subjects such as developing effective communication, improving the quality of care, improving the satisfaction of the patients and service providers, providing better performance measures for the services, and aiding strategic planning; and also very large benefits are obtained in those fields (Işık and Akbolat, 2010).

Nursery informatics is improving rapidly today as it provides easy preparation of nursing schedules and in the time spent at patient's bedside. But today there are some factors which greatly influences nursery informatics. Ethics and patient privacy are the most crucial issues in nursery informatics that should be taken into consideration in the first row (Thede, 2003). 
Scientific and technological advancements especially in biomedical scope, have made it possible for the individual to sustain his life by intermeddlings like revival of a stopped heart, maintenance of respiration by an artificial respirator, replacement of lost function through transplantation of organs. On the other side, these opportunities have led to gradual ambiguousness in the border between death and life, complexity in care functions or occurance of ethical problems. Ethical problems require moral judgements and make choices but they are such type of problems that don't have precisely right or wrong solutions, they are complicated and leaves the person in contradiction as well (Dinç, 2009). Most of National Nursery Ethical Rules are predicated on "Codes of Ethics for Nurses" of International Council of Nurses. It is specified among these ethical rules/codes under the subtitle "Nurses and Practices" that scientific developments and use of technology should be in conformity with human rights, honour and safety, considering ethical problems caused by advanced science and technology (Dinç, 2009).

\section{Telemedicine, telenursery and ethics}

Telemedicine among electronic health services can be in general means defined as conveyance of health-related services to non-hospital distances by using information technologies. Information about diagnosis, consultation, treatment or education can be sent and received in this way. Telenursing issue on the other hand has evoked additional tough ethical anxieties in nursery ethics which is already very controversial. Moreover, it has been ascertained that most of traditional nursery ethical problems are valid for telenursing as well (Wynchank and Fortuin, 2011).

\section{Health service, health enterprises and the profession}

Health service includes basic human rights. Preservation of health right and equal, sufficient, attainable health care service for everyone is the professional and ethical liability of health staff.

Existence and development of a profession depends on the service it provides for public. Public gives some assets and privileger like respectability and dignity to specific jobs as a response to their service that is needed by the society (Dinç, 2009). Health reform efforts initialized in Turkey in 2003, basically comprises four groups as organization in ehealth service, privacy and secrecy, techniques and practices. In sub-groups of privacy and secrecy; retention of audit records, person verification, system verification, authorization, control of data integrity, error handling, safe handling and nonrepudiation basically take place (Cengiz, 2007).

As the fundamental requirement of health services, health enterprises are the constitutions where high confidence factor is kept the foremost in operational processes, diagnosis, consultation and treatment. Modern health services should be capable of providing instant, rapid, complete and correct solutions to beneficiaries. However, needs and expectations of health delivery suppliers and beneficiaries vary from day to day. Progressing innovations and solutions in health along with all other variable components should be combined under the light of ethical principles. Therefore, it is essential for health enterprises to follow innovations very closely in addition to begin human resources activities.

\section{Health care and ethics}

It is accepted that health is a fundamental human right and humans possess equal rights to receive equal, attainable, costfree and qualified health care to remain healthy, to improve their health, and to regain health when they fall ill (TTB, 2008).

Concept of professional ethics in nursery arises from the ethical dimension of health care concept. This is of particular importance in issues like developing perspective on ethical problems in nursing practices, protecting patient rights and provision of patient's safety (Dinç, 2009).

Among all health staff teams, nurses comprise the largest health group who provides direct patient care, determine their needs and decides where and when the equipments and materials will be used. Therefore nurses are primary users of the system adapted to computer environment. Many quantitative and qualitative data are recorded by access into registration system by nurses. Maintenance of patient care and treatment besides improvement in the quality of care is expected due to interdisciplinary data entries. These data do not only underlie the basis to develop nursery information system by supporting nursery practices but also form the basis for other hospital information systems. But connection between nursery records and other health care professionals' records should be completed so that nursery records are able to be effectively and efficiently shared (Top and Gider, 2010).

Nurses feel the need to consider physical, mental and social requirements of patients as a whole and by the help of electronic medical recording systems, they are able to check diagnosis and physician demands, make out nursery care plans, record vital signs of patients, follow up patients' laboratuary results and many other medical recording processes (Top and Gider, 2010).

6. Data security in health care and essential points for ethics There are three aspects of data security; first one is data accuracy. Second one is protecting data from unauthorized people both inside and outside and the third one is preventing internal and external damage to data. Precision of original data is under the responsibility of the user. User should ensure that data are not altered. Additionally, he/she should never give the password to anyone and always preserve data from curious eyes. At the same time, data should be saved without being lost and backup of data should be created regularly and saved safely. Furthermore, a disaster recovery plan should be evolved and tested. Responsibility of patient privacy protection is over health professionals (Thede, 2003). Conservation of patients' data in informatics and nursery consists of three divisions. These are secrecy, privacy and safety. Privacy means patients' selection of those who will share their private information. Secrecy is the determination of those who can access to patient's health information and restriction to the rest. They decide to make information, shared with the health care provider, known by others. Security division, on the other hand deals with data protection and system errors. Preservation of patient secrecy is the liability of every health professional as protection of patient data is extremely crucial. When the environment is created for a patient interview, it should be provided that interview will be confidential not allowing others to listen. Additionally, patients should be given 
the opportunity to choose among family members, spouses or any other person who will accompany or who will leave the room during interview (Thede, 2003).

Necessary maintenance of computers should be fulfilled which informational data is input. Personal computer (PC) screen should not be allowed to be seen by anyone other than the data entry person (Thede, 2003).

Earlier, it was not easy to access the system or to access more than one record at one time whereas it is much more convenient now for health staff to access health data. On the other hand, electronical data records have foregrounded privacy problem. Access to the system is presently provided by a verifying login process peculiar to system user. Identity verification has been statistically proven as the safest method. It can be implemented by using physical particulars like fingerprint scanning, retina or iris scanning or a customized unique voice record (Thede, 2003). The second safest system is card or key login method accompanied by a password. Most of the systems don't allow permanent use of the same password and forces to change it from time to time to enhance safety. What should not be avoided is that the data which health staff is occupied with belongs to humans and includes vital information about them therefore should be preserved like a treasure. Nurses should ensure that they have logged out or they have left no visible data on the screen when they are leaving the patient's room as family members or visitors inside may see them (Thede, 2003).

Some systems have been being used in some developed countries for many years. This has made it possible in those countries to discuss positive and negative aspects of the system's use. For example, according to a research in Canada on daily ethical controversies caused by electronic medical record systems in the primary care; entrance of electronic medical record systems into primary care has changed work practices led to emergence of new roles and new problems. Ethical issues related to use of primary care was debated in three areas; ethical issues that came into existence as a result of changes in service practices, ethical issues about access and ethical issues related to administrative loopholes (Balka and Tolar, 2011). Emphasis on information technologies in health services is gradually increasing so it is quitely important for health staff to utilize information technologies to achieve effective, efficient and qualified delivery of health services (Iș1k and Akbolat, 2010).

Some scopes that require ethical and legal regulations are auditing of accesses to health records and secrecy principles. Preservation of personal data in digital environments, ability to access these data from wherever needed on condition that person's permission is taken, and common use of statistical results on social data conditional that individual privacy is ensured, may all considerably enhance (Marşap et al., 2010).

\section{Suggestions}

Common standards are required to share health information easily on need; audit and inspection systems are required to preserve information secrecy (Marşap et al., 2010). Additionally solutions should be produced being aware of health problems brought about by globalization. In order to achieve all these qualifications and struggle for ethics that is one of the crucial issues in global health, education comes in the foremost (Kaya, 2010).

On literature about information ethics; physicians, nurses, and assistant doctors, paramedical staff, students of health sciences, patients and government executives were mentioned as the potential users of informatics systems. While health information ethics is discussed among these major groups, it is suggested to include practitioner nurses, pharmacists, administrators, scientists, researchers, computer experts and other medical assistants as well (Zekios and Petroudi, 2006).

A systematic approach to evidential studies indicates that safe and adequate technical solutions will provide a significant contribution to overcome the barriers against advancement of electronic-health (Duplaga and Zielinski, 2006). Consequently, reflection of globalization and health informatics on health care ethics is more and more increasing. Therefore, team members also should take these improvements into consideration during health care delivery. Education has a significant role in following technological advancements as well as carrying out current ethical rules during health care delivery where health informatics is effectual.

\section{REFERENCES}

Balka, E., Tolar, M., 2011. Everyday ethical dilemmas arising with electronic record use in primary care. In: Anne Moen, Stig Kjaer Anderson, Jos Aarts, Petter Hurlen. (eds). User Centred Networked Health Care. Proceedings of MIE. 285-290.

Cengiz, S.A., 2007. İnternet ve etik: Örnek uygulama alanı olarak sağlı iletişimi. XII. “Türkiye'de İnternet” Konferansı 8-10 Kasım, Ankara. 292-305.

Çukurçayır, M, A., Çelebi, E., 2009. Bilgi Toplumu ve E-Devletleşme Sürecinde Türkiye. ZKÜ Sosyal Bilimler Dergisi. 5, 59-82.

Dilmen, N.E., 2007. Bireyselleşen Küre. In küreselleşme üzerine notlar, Oğuz Kaymakçı, O., (ed). Nobel yayın dağıtım, Ankara, available from URL: www.sertacogut.com/blog/wp- ontent/.../03/bireysellesen-kure.pdf.

Dinç, L., 2009. Hemşirelik hizmetlerinde etik yükümlülükler. Hacettepe Tıp Dergisi. 40, 113-119.

Duplaga, M., Zielinski, K., 2006. Chapter 1, Evolution of IT-Enhanced Healthcare: From Telemedicine to e-Health. In: Duplaga M., Zielinski K, Ingram D. (eds). Health Informatics (formerly Computers in Health Care) Kathryn J. Hannah Marion J. Ball (Series Editors) Springer-Verlag London Limited, 17.

Işık, O., Akbolat, M., 2010. Bilgi Teknolojileri ve Hastane Bilgi Sistemleri Kullanımı: Sağlık Çalışanları Üzerine Bir Araştırma. Bilgi Dünyası, 12, 365-389.

Kaya, H., 2010. Küresel sağlığı geliştirmede hemşirelik eğitimi. Uluslararası İnsan Bilimi Dergisi. 7, 360-365.

Marşap, A., Akalp, G., Yeniman, E., 2010. Sağlık işletmelerinde insan kaynağının kurumsal bilgi güvenliği kültürü gelişimi. Bilişim Teknolojileri Dergisi. 3, 31-40.

Ömürbek, N., Altın, F.G., 2009. Sağlık Bilişim Sistemlerinin Uygulanmasına İlişkin Bir Araştırma: İzmir örneği. SDÜ Fen Edebiyat Fakültesi Sosyal Bilimler Dergisi. 19, 211-232.

Seçginli, S., Erdoğan, S., 2012. 11. Uluslararası Hemşirelik Bilişimi Kongresi: Bilişimim Yoluyla Global Sağlığın Geliştirilmesi. Smyrna Tıp Dergisi. 2, 53-54.

Thede, L.Q., (ed)., 2003. Ethics in nursing informatics. Informatics and nursing: Opportunities and challenges. Lippincott $5^{\text {th }}$ Edition. Available 
from URL: http://estherschiavello.blogspot.com/.

Top, M., Gider, Ö., 2010. Hemşirelerin elektronik tıbbi kayıtlara ilişkin görüşleri: Kullanım, kalite ve kullanıcı tatmini. International 8th knowledge, Economy \& management congress proceedings. (8. Uluslararası Bilgi, Ekonomi ve Yönetim Kongresi Bildirileri Kitab1). $1036-1048$.

Türk Tabipler Birliği (TTB) etik bildirgeler çalıştayı sonuç raporları. Türk Tabipleri Birliği Yayınları, Ankara. 2008.

Wynchank, S., Fortuin, J., 2011. Telenursing in Africa, Ethical Questions in Telenursing. In: Sajeesh Kumar, Helen Snooks (eds). Health Informatics. New York, 125.

Zekios, A., Petroudi, D., 2006. Artificial intelligence in medicine and biomedicine. Chapter XLIII., Idea group Inc., Athina Lazakidou. Informatics in Healtcare and Biomedicine. 346-352. 